\section{HDTV off to slow start}

\section{Tokyo}

JAPAN took a step ahead of the rest of the world in the development of high-definition television (HDTV) on 26 November with the start of regular HDTV broadcasts via satellite. Japan's HDTV has crystalclear pictures that contain twice as many lines as conventional television. But most Japanese viewers of the new HDTV channel will probably not see the high-quality pictures because they will tune in on modified conventional television sets rather than HDTV sets, and the future of Japan's HDTV is uncertain.

The Japanese government, the National Broadcasting Corporation (NHK) and industry have invested more than $\$ 1,000$ million over 20 years in developing HDTV. But with the start of the new HDTV broadcasts, Japanese electronic companies are not trying to sell consumers HDTVs, which currently cost about $\$ 30,000$ each. Instead, they are promoting sales of much cheaper - yet still expensive - conventional televisions that have been modified to receive and display the HDTV signals.

The modified televisions are equipped with converters that translate the complex HDTV signals into a form an ordinary television can deal with. Some have wide screens that can display the full wideangle HDTV picture. But the cheapest versions, priced at about half a million yen $(\$ 3,800)$, have only slightly widened screens that cut off the HDTV picture at the sides. Nevertheless, these seem to be the ones in most demand.

Japanese manufacturers are rushing to bring down the price of real HDTVs by developing cheaper sets of semiconductor chips for the televisions. HDTVs require a high-performance computer, called a decoder, that reads and translates the vast amount of information contained in HDTV broadcasts. Japanese companies have teamed up with US manufacturers to de- velop the new chip sets, and cheaper second-generation decoders should be on the market late next year. Industry's ultimate goal is to bring the price of HDTVs down to $¥ 1$ million $(\$ 7,600)$ in time for the Atlanta Olympic games in 1996, by which time they hope about 5 per cent of Japan's 40 million homes will have HDTV.

But many industry observers question whether consumers actually want to see high definition pictures at that sort of price. "Twenty years ago, NHK decided people wanted more lines on their TV screens, but what they actually want is more choice", says Bob Johnstone, Technology Correspondent for the Far Eastern Economic Review.

Johnstone and many other industry observers believe the future of television lies in a much wider choice of channels combined with new computerized televisions that will allow viewers to interact much more with their televisions.

Even if HDTV takes off, it is questionable whether it will be based on the system currently in use in Japan. The present Japanese system broadcasts analog signals just as does conventional television. But last year, the US company General Instrument announced development of a compression technology that the US company claims will allow transmission of HDTV signals in digital form, and most people in industry now believe that HDTV of the near future will be digital.

But this does not mean that Japan will be leapfrogged by the United States, as some observers have suggested. All of Japan's major electronic manufacturers are now working on development of digital HDTV, and the Ministry of Posts and Telecommunications plans to launch a Communications and Broadcasting Engineering Test Satellite (COMETS) in early 1997 that will test digital HDTV broadcasts.

David Swinbanks
Canada targets biotech

\section{Montreal}

Altholgh Canada has not been as quick as other nations to recognize the importance of biotechnology to industrial growth, that situation is now changing. In recent weeks, the federal government has released a report aimed at strengthening the Canadian biotechnology industry, and both Canada's science minister and the president of the National Research Council (NRC) have taken up the issue.

National Biotechnology Business Strategy: Capturing Competitive Advantage for Canada finds a variety of obstacles hampering Canadian biotechnology development, including a lack of risk capital, trained managers and technicians, delays and uncertainties in governmental regulatory procedures, and a patent system that has produced a backlog of nearly 2,500 patents pending from as far back as 1979 . At the rate patents are being awarded, the backlog would take 50 years to clear.

The report's recommendations include: creating funding pools of $\$ 35$ million to $\$ 50$ million for small-company investment, offering investors tax incentives and encouraging joint industry-provincial development funds;

- setting up high-technology company management courses, and making immigration easier for foreigners with required skills;

upgrading university research through support of indirect costs; and

- streamlining regulations and patent laws and harmonizing them internally and with those of other countries.

Science Minister William Winegard told a press conference on 25 November that Canada has the brains to develop a world-class biotechnology sector, "but we haven't had the will or the way to clear some of the debris out of the way." He lauded the report and urged changes in industry's attitudes.

Nine days later, NRC president Pierre O. Perron told the agency's 6th Industrial Biotechnology Conference in Montreal that, after a year's thorough examination of its own biotechnology programme by another group of outside experts, "NRC is preparing a strategic plan for its longterm commitments in this area".

The outside evaluation of this programme took place as NRC celebrates its 75th anniversary. Perron said it was done at a time when the agency's activities are moving from laying biotechnology's foundations to a "second phase" where industry is commercializing its products.

More than 200 Canadian companies already use biotechnology, but the report identified four areas in which significant market opportunities are matched by Canadian strengths: waste management, forestry, food and agriculture, and human biopharmaceuticals. David Spurgeon innovation and technological development 